\title{
A clinical severity grading scale for Marfan syndrome
}

\author{
Jonathon R Gray, Sarah J Davies
}

\begin{abstract}
There is considerable interest in assessing patients with Marfan syndrome at the clinical, protein, and genetic levels. Clinical assessments are inconsistent between centres and between clinicians. There are no satisfactory clinical grading scales against which to analyse the molecular information, limiting the scope of clinical/ molecular correlations. We present grading scales for the major clinical systems involved in Marfan syndrome and suggest that their widespread use will facilitate collaborative approaches to clinical/ molecular correlations and international assessments of therapy.

( $\mathfrak{7}$ Med Genet 1996;33:758-759)
\end{abstract}

Key words: Marfan; severity; grading.

Marfan syndrome is an autosomal dominant disorder of connective tissue with an incidence of $1: 9800$ and a prevalence of approximately $1: 14000 .^{1}$ Since the discovery that fibrillin protein abnormalities are the pathological basis for Marfan syndrome ${ }^{2}$ many centres are assessing the Marfan syndrome families available to them for abnormalities at the DNA and protein level.

A clinical grading scale for Marfan syndrome severity is vital to allow useful correlation of clinical findings with the mutation and protein analysis data. Any grading system must be based on an assessment of the severity of a particular clinical feature within the various affected members of a given family. Any given mutation will produce a spectrum of clinical features dependent on modifying genetic and environmental factors present in a person. The mean value for a given clinical feature within affected members of a family will be the closest approximation to the "true" value. We do not intend this grading scale to act in any way as a diagnostic aid. All patients should be diagnosed strictly according to the criteria detailed in the Berlin nosology. ${ }^{3}$ Only after diagnosis can the severity grading scale be applied.

In previous studies ${ }^{1}$ we have recorded the cardiovascular and skeletal severity of affected Marfan syndrome patients on an individual basis using grading systems similar to those outlined in tables 1 and 2 . We have broken down both the cardiovascular and skeletal gradings with respect to age, thereby taking account of the evolution of the phenotype. Cardiovascular measurements demand accurate, consistent imaging of the aortic root at the level of the sinuses of Valsalva. ${ }^{4}$ We do not include isolated mitral valve prolapse in the cardiovascular criteria because of its relatively low specificity for Marfan syndrome.

Vertebral deformities are a common cause of skeletal morbidity with scoliosis/kyphoscoliosis occurring in between 30 and $60 \%$ of Marfan syndrome patients. ${ }^{5}$ Within the skeletal grading scale we have attempted to take account of the variable severity of vertebral deformity. We would suggest that a person requiring surgery for scoliosis scores 2 for having scoliosis and for requiring treatment for it. Joint hypermobility is assessed by the criteria of Beighton $e t$ $a t^{6}$ and defined as being present if scoring greater than $5 / 9$. Pectus excavatum is caused by overgrowth of tubular bone, specifically the ribs, pushing the sternum into an abnormal anterior (pectus carinatum) or posterior (pectus excavatum) position or producing a combined deformity. Examination of the palate is a subjective but usually relatively simple assessment of the palatal height and degree of narrowness, a high arched palate usually being associated with overcrowding of the teeth and malocclusion. The simple assessment of span being greater than height is of no value alone as this can be observed in approximately $59 \%$ of normal males and $21 \%$ of females. ${ }^{7}$ Of more value is the observation that a span exceeding height by greater than 3 inches is only observed in $5.6 \%$ of normal patients. ${ }^{7}$ The upper segment/lower segment ratio varies with age, but for Marfan syndrome patients is typically at least 2 standard deviations below the mean for age, sex, and race, as detailed by $\mathrm{McKu}$ sick.

Respiratory complications are seen in Marfan syndrome ${ }^{3}$ and we have included pneumothorax in the skeletal grading scale.

The ocular grading system is not adjusted by age as the frequently severe myopia usually appears early. Similarly any lens subluxation is usually an early event.

We suggest that these grading scales can be extended with the addition of a similar scale for ocular abnormalities (table 3 ). Cut off points, as shown in tables 1 to 3, can be decided upon to allow allocation of "mild", "moderate", and "severe" phenotypes for each of the three clinical systems classically affected in Marfan syndrome. Some clinical features in both the cardiovascular and skeletal gradings show an evolution with age, and the scales are arranged to take account of the age specific nature of these features.

Cardiovascular gradings have been applied to Marfan syndrome ascertained in Scottish and Welsh populations. ${ }^{9}$ Using the suggested scale, severity of cardiac phenotype is con- 
Table 1 Cardiovascular severity grading

\begin{tabular}{lll}
\hline Clinical features & Grade & Phenotype \\
\hline No cardiovascular features & 0 & Normal \\
Aortic dilatation, not requiring surgical intervention, observed over the age of 40 years & Mild \\
Aortic dilatation observed between the ages of $20-40$ years & Moderate \\
Aortic dilatation under 20 years of age or surgical treatment of aortic or mitral valve disease or aortic & 2 & 3 \\
dissection & Severe \\
\hline
\end{tabular}

Table 2 Skeletal severity grading

\begin{tabular}{|c|c|}
\hline \multicolumn{2}{|l|}{ Clinical features } \\
\hline \multicolumn{2}{|c|}{$\begin{array}{l}\text { (1) Kyphosis } \\
\text { (2) Kyphosis limiting exercise or requiring surgical } \\
\text { intervention } \\
\text { (3) Scoliosis } \\
\text { (4) Scoliosis limiting exercise or requiring surgical intervention } \\
\text { (5) US/LS ratio }>2 S D \text { below mean for age, sex, and race } \\
\text { (6) Joint hypermobility ( }>5 / 9 \text { on Beighton scale) } \\
\text { (7) Pectus deformity (excavatum/carinatum or combination) } \\
\text { (8) High arched palate } \\
\text { (9) Span }>\text { height }>7.5 \mathrm{~cm} \text { in an adult } \\
\text { (10) Pneumothorax }\end{array}$} \\
\hline No of skeletal features & Phenotype \\
\hline $\begin{array}{l}<2 \\
2-4 \\
5-6 \\
7+\end{array}$ & $\begin{array}{l}\text { Normal } \\
\text { Mild } \\
\text { Moderate } \\
\text { Severe }\end{array}$ \\
\hline
\end{tabular}

firmed as the major prognostic indicator for survival. ${ }^{9}$ Family severities, and by extension an estimate of severity attributable to a particular fibrillin mutation, can be assessed by taking the mean severity scores for all the affected members. It may be possible to assess the effects of a particular fibrillin mutation against the effects of other putative genes in a family. ${ }^{10}$

We present new clinical grading scales for use in Marfan syndrome and suggest that only with the widespread and uniform use of such scales can information from the many inter-
Table 3 Ocular grading system

\begin{tabular}{lll}
\hline Clinical features & Grade & Phenotype \\
\hline No ocular features & 0 & Normal \\
Severe myopia ( $>6$ diopters) & 1 & Mild \\
$\begin{array}{l}\text { Severe myopia plus retinal } \\
\text { detachment }\end{array}$ & 2 & Moderate \\
Lens subluxation/dislocation & 3 & Severe \\
\hline
\end{tabular}

national centres be used in any collaborative fashion for phenotype/genotype correlations.

1 Gray JR, Bridges AB, Faed MW, et al. Ascertainment and severity of Marfan syndrome in a Scottish population. $\mathcal{f}$ Med Genet 1994;31:51-4.

2 Hollister DW, Godfrey M, Sakai LY, et al. Immunohistologic abnormalities of the microfibrillar-fiber system in the Marfan syndrome. N Engl f Med 1990;323:152-9.

3 Beighton P, de Paepe A, Danks D, et al. International Beighton P, de Paepe A, Danks D, et al. International
Nosolugy of Heritable Disorders of Connective Tissue, Nosolugy of Heritable Disorders of Connective
Berlin, 1986. Am $\mathrm{f}$ Med Genet 1988;29:581-94.

4 Roman MJ, Devereux RB, Kramer-Fox R, et al. Two dimensional echocardiographic aortic root dimensions in normal children and adults. Am f Cardiol 1989;64:507-12.

5 Ramirez F, Godfrey M, Kramer-Fox, et al. Marfan syndrome and related disorders. In: Scriver CR, Beaude AL, Sly WS, Valle D, eds. The metabolic and molecular base of inherited disease. 7th ed. New York: McGraw-Hill, 1993:4079-94

6 Beighton P, Grahame R, Bird H. Hypermobility of joints. London: Springer-Verlag, 1989:149-70.

7 Pearson $\mathrm{K}$, Lee A. On laws of inheritance in man. I. Inheritance of physical characters. Biometrika 1902;2:357-462.

8 McKusick VA. Heritable disorders of connective tissue. St Louis: C V Mosby, 1972.

9 Gray JR, Bridges AB, West R, et al. Life expectancy in British Marfan syndrome populations. $\mathcal{F}$ Med Genet (submit-
Med ted)

10 Pereira L, Levran O, Ramirez, F et al. A molecular approach to the stratification of cardiovascular risk in families with Marfan syndrome. N Eng $\mathcal{F}$ Med 1994;331:148-53. 